\title{
Digital Archiving of Archaeological Resources in Flanders (Belgium): a brief review
}

\author{
Piraye Hacıgüzeller, Koen Van Daele, Frank Carpentier and Raf Ribbens
}

\section{Summary}

This article provides an overview of the current state of archaeological digital archiving in Flanders (Belgium). It briefly outlines the legally defined stakeholders and actors through which archaeological fieldwork is regulated and carried out. It subsequently describes related digital documentation and archiving practices, and guidelines. This is followed by a discussion on compliance with the FAIR Guiding Principles, and the article concludes with notes on the past and future of archaeological digital archiving in Flanders.

\section{Archaeology in Flanders}

Within Belgium's federal political constellation, heritage is a devolved competence, which means archaeological research is regulated by its different constituent regions (i.e. the Brussels Capital Region, Flanders and Wallonia). In Flanders, archaeological research is subject to new heritage legislation that took effect in April 2016 consisting of the Immovable Heritage Decree (Dutch Onroerenderfgoeddecreet, cf. Vlaams Parlement 2013) and the Immovable Heritage Order (Dutch Onroerenderfgoedbesluit, cf. Vlaamse Regering 2014). This legislation sought to implement the tenets of the Valletta Treaty and introduced a system of legally defined actors (i.e. archaeologists, metal detectorists, heritage depots, heritage municipalities and intermunicipal heritage services) accredited by the Flanders Heritage Agency (henceforth Flanders Heritage). These actors must meet certain requirements in order to receive and remain eligible for accreditation. Apart from defining the actors, the legislation also defines processes (e.g. listing of monuments, landscapes or cityscapes, archaeological research, metal detection finds reporting) and provides a system of government subsidies and grants aimed at supporting accredited actors and heritage owners. 
Flanders' heritage legislation differentiates between voluntary archaeological research initiatives, often driven by purely scientific research questions and carried out by research institutions, and research generated from spatial planning initiatives, usually undertaken by accredited archaeological contractors. The overwhelming majority of archaeological research in Flanders is undertaken by the latter as archaeological research can be a mandatory requirement for a building or zoning permit. Archaeological contractors must follow regulations enforced by Flanders Heritage or accredited heritage municipalities where applicable. This ensures a high degree of compliance. The execution and publication of archaeological research is regulated by a Code of Good Practice (Agentschap Onroerend Erfgoed 2019) and is the legal prerogative of archaeologists accredited by Flanders Heritage.

The accreditation of actors is based on quality, ability and organisational capacity standards that candidates are expected to meet. These qualifications are translated into actor-specific accreditation criteria. Accredited metal detectorists, for instance, only need to prove they have reached the age of majority and have not been convicted of crimes involving heritage law in the European Union over the past five years. By contrast, the criteria accredited heritage depots must adhere to are considerably more elaborate. They must meet more than a dozen criteria, ranging from having appropriate storage facilities and staff to presenting emergency and discontinuation plans, proving sound financial and operational management, and investment in public outreach efforts. Qualifications for accredited heritage municipalities and accredited intermunicipal heritage services are similarly elaborate but instead have more emphasis on policy making, formulating long-term approaches to local heritage management and raising public awareness. The requirements for accredited archaeologists, on the other hand, focus on training qualifications, fieldwork experience and access to appropriate storage facilities.

Any applicant who meets the requirements receives an accreditation. Accreditations are permanent, provided the actors abide by the heritage law. Flanders Heritage both coaches and supervises the accredited actors. Accredited heritage depots, accredited intermunicipal heritage services and accredited heritage municipalities report annually to Flanders Heritage. Accredited archaeologists do not because they frequently submit different types of research documents over the course of each archaeological project. Accredited metal detectorists only report their finds on a web-based metal detection finds form. When an accredited actor fails to comply with the law, Flanders Heritage can evaluate the accreditation and, if necessary, suspend it. The suspension period offers the actor a chance to justify and/or redeem themselves. Should the actor fail to do so, then Flanders Heritage can revoke the accreditation. Individuals whose accreditation has been revoked, are disqualified from applying for a new accreditation for a year.

\section{Documentation and Archiving of Archaeological Fieldwork}

Reporting fieldwork is mandatory in Flanders. Non-compliance may cause archaeologists to lose their accreditation. Regardless of who undertakes archaeological research (e.g. academic, private or governmental), the type of research (e.g. preliminary research to assess the archaeological potential of a locality or excavation) or what triggered the investigation (e.g. scientific interest or urban planning), the regulations for 
reporting and handling the research archive are identical. Archaeology assessment reports (Dutch archeologienota) made as part of the spatial planning process are submitted to a central digital platform, Archaeoportal (Dutch archeologieportaal). These reports serve both as research documentation and as a mandatory annexe to a building or zoning permit. Parts of Archaeoportal are only accessible to authenticated users (e.g. accredited archaeologists, Flanders Heritage staff). However, upon submission, archaeology assessment reports are evaluated by Flanders Heritage or an accredited heritage municipality when applicable and are subsequently made available to the general public on Archaeoportal. The platform is developed, run and maintained by Flanders Heritage, free of charge. This ensures that all recent archaeological research is available to the general public in a single location rather than dispersed over different websites.

The archaeology assessment report contains the results of the preliminary research and suggests what further measures are required to safeguard the archaeological potential of a site (e.g. no measures, in situ preservation, full-scale excavation, archaeological supervision during development). If an excavation is carried out, the archaeologist responsible submits a preliminary archaeological report (Dutch archeologierapport) to Flanders Heritage. This is not a comprehensive field report, but a short preliminary account that details general results, major finds and required analyses. Preliminary reports are not available to the general public. Within two years of finishing fieldwork, the accredited archaeologist publishes and submits a final report (Dutch eindverslag) that is made publicly available on Archaeoportal.

Each submitted archaeology assessment report or final report consists of the actual report, some related research documents and metadata. Importantly, the submitted reports do not include the complete set of research documents produced as a result of the fieldwork. Only a selection of the most relevant documents (in pdf) has to be submitted as an annexe to the report (e.g. list of findings, list of registered features). In a way, these documents are a preview of what an interested researcher could find in the complete archaeological assemblage. The term 'archaeological assemblage' here refers to the full documentary archive of the fieldwork and, as such, not only includes the finds and samples but also all maps, drawings, photographs, research data, lists, descriptions, and the report itself. Most of the metadata submitted with reports is administrative in nature, concerning things such as authorship, which additional steps are required in the archaeological process, the spatial extent of the research and the nature of the complete archaeological assemblage.

Regarding guidance for fieldwork documentation and archiving, the Code of Good Practice dedicates two chapters (6 and 14) to technical requirements for fieldwork documentation, mainly to regulate content creation and metadata entry. It defines which information should be registered and even provides a limited set of values for certain data entries. For instance, the required metadata for each photograph in a collection should contain: the unique project code (allocated by Flanders Heritage), a unique picture identification, the type (e.g. archaeological find, archaeological feature, stratigraphic profile, etc.), the date, the spatial zone or area identification, and an identification of the archaeological feature(s) appearing in the photograph. In addition, the Code of Good Practice regulates the digital format of the research documents, which should either be born-digital or be digitised. Digital files, for instance, must conform to open standards, be suitable for durable preservation, readable by non-proprietary software, and not be encrypted or password protected. Digital files have to comply with certain quality standards too. Photographs, for example, require a minimum resolution, 
and the camera also needs to meet certain quality standards. Inventories of archaeological entities must be suited for automated text-searching, sorting, filtering and querying. Lastly, the Code of Good Practice imposes rules on the preservation of digital research documents (chapter 31 ). It specifies, for example, that such files should be stored on a flash memory storage device, formatted in a standardised file system and structured in compliance with the ISO-9660 standard. The documents must include metadata that complies with the Dublin Core metadata standards and a checksum for all digital files that serves to verify whether the consulted version of a file is still the one included in the original digital archive.

According to property rights in the Belgian Civil Code, the ownership of archaeological finds remains with the landowner. Nevertheless, the Immovable Heritage Decree obliges the owner of an archaeological assemblage to preserve the assemblage as an inseparable whole, in good condition and accessible for further study (De Langhe 2018). Some of the archaeological assemblages are deposited at accredited heritage depots. In 2020, there were 15 such depots across Flanders, one of them being the depot of Flanders Heritage itself. Except for one privately established depot, all accredited heritage depots originate from public sector initiatives (Ribbens and De Groote 2020). Depositing assemblages at a depot (accredited or otherwise) is not mandatory; if the owner of the archaeological assemblage is able to provide sufficient care, they can choose to keep the assemblage themselves. Some of the accredited depots are associated or closely related to an archival institution (e.g. a museum or archive) and are therefore familiar with best practices for digital storage and maintenance.

Accredited archaeologists are legally obliged to disclose the location of the assemblage as metadata when uploading the archaeology assessment report or final report to Archaeoportal. Although the reports are published online, the location of the assemblage (and a small number of other metadata) is not disclosed publicly as it might contain information subject to the European Union's General Data Protection Regulation (GDPR) rules. If assemblages change location afterwards, the owner is legally obliged to notify Flanders Heritage, which, since 2016, has operated a central registry for all archaeological assemblages found in Flanders. Besides storage location, the registry contains the names, addresses and contact information of owners and users for every archaeological assemblage. As such, the registry indexes the archaeological assemblages, but it does not enable direct access to and consultation of the contents since it does not host or provide links to the digital resources involved. Despite these limitations, the registry remains useful for tracking down fieldwork locations and consulting related attributes, as well as the locations of the resultant archaeological assemblages, mainly by authorised users (e.g. Flanders Heritage staff). Its consultation by the public is technically possible but not user-friendly and, as discussed, involves limitations in terms of content in order to comply with GDPR rules.

\section{Compliance with FAIR Guiding Principles}

When comparing the FAIR Guiding Principles with current digital documentation and archiving guidance and practice in Flanders, the conformity is reasonably high. This is not surprising as the first version of the Code of Good Practice was written according to the FAIR Principles although it does not mention them explicitly. Archaeoportal was 
created in 2016 with the long-standing best practices employed by Flanders Heritage in mind. Most of these also align well with the FAIR Principles, since Flanders Heritage has consistently been in favour of publishing open data. It has kept abreast with developments in this field and with the general vision of the Flemish Government regarding open data (Vlaamse Regering 2011; Vlaamse Overheid 2018). Basic aspects of FAIR, such as providing permanent, dereferenceable unique identifiers, have been included when creating information systems for Flanders Heritage since 2009. In that sense, Archaeoportal is exemplary of other Flanders Heritage information systems as they follow similar design choices inherent to the IT architecture of the entire organisation (Van Daele et al. 2018).

Information resources published on the Flanders Heritage web platform are findable since every information resource on the platform is assigned a unique identifier (F1; cf. Wilkinson et al. 2016) in accordance with the Flemish Government's URI standard for data (Vlaamse Overheid 2017). Moreover, each resource is provided with a metadata description (F2, F3) that can be searched and queried on the platform itself (F5).

The data on the web platform are accessible since they can be retrieved through several well-known, open protocols (A1, A1.1). Basic access is provided through simple HTML pages accessible through the HTTP protocol. A REST service using the HTTP protocol is available and renders all information object data, including the geospatial data in GeoJSON format, available for automatic retrieval. This service can be accessed by anyone with sufficient knowledge of REST services through the submission of a GET request with an HTTP Accept header set to application/json and an endpoint with a unique identifier (e.g., final reports). However, while using this REST service is technically possible (and used every day by Flanders Heritage's internal software), there is no publicly available documentation on this aspect of the web platform. So far, public adoption of the REST services remains low or non-existent (see 4. Conclusions). Geospatial data stored in Archaeoportal (concerning, for instance, locations of fieldwork) can easily be consulted by users who do not use specialised GIS software through the Flanders Heritage Geoportal. Geospatial geometries can also be retrieved through downloads or geo-web services using WMS and WFS protocols. Users with access privileges can authenticate themselves both on Archaeoportal and Geoportal to access additional information and information objects that are inaccessible to the general public owing to, for instance, GDPR rules (A1.2). All metadata are stored in perpetuity by Flanders Heritage (A2).

The metadata are somewhat interoperable since they are available as JSON at a dereferenceable URI (I1). They feature links to other metadata such as the Flemish Central Address Database (Buyle et al. 2019) and ISO country codes (I3). The controlled vocabularies used in Archaeoportal, like most vocabularies used by Flanders Heritage, are published as SKOS-data (Mortier et al. 2017) at the Flanders Heritage Thesaurus (I2). However, while the metadata are available as regular JSON, they are not elevated to JSON-LD or backed by a formal RDF ontology, so adherence to subprinciple I1 can be seen as partial.

Admittedly, the reusability principle requires more work. The provenance of the data is generally clear since Archaeoportal records who submitted or created a certain information resource (R1.2). We are unaware of whether a single international standard exists for the information resources provided by Flemish Heritage. The Code of Good Practice, however, can be considered as the underlying Flemish community standard. Certain metadata, such as geographic metadata, do adhere to international standards 
such as GeoJSON (R1.3). The published metadata should certainly be provided with a clear and unambiguous licence, which it currently does not have (R1.1). It could also be argued that more metadata ought to be created and made openly available such as information on site type (e.g., settlement, burial) or period (e.g., Iron Age, medieval, First World War). While this would undoubtedly be useful, requesting this information at the point of report submission would also require additional time and recording efforts from the archaeologists. Since most of these submissions are done by archaeological companies, such additional requirements would represent an unwelcome, significant economic cost. Alternative options for generating this type of metadata would be postsubmission, either manually (by Flanders Heritage archaeologists) or automatically (e.g., through natural language processing algorithms). But again, these options too would come at a significant cost, mainly in terms of the digital services infrastructure when applicable, and time that would be required for manual metadata extraction or editing to obtain high quality metadata.

\section{Conclusions}

Archaeoportal, the central web platform of Flanders Heritage since 2016, generally adheres to the FAIR Principles, but this could be improved even further. Firstly, a relatively simple and straightforward improvement would be to make licensing information about the published metadata more explicit. Secondly, the available services should have more robust documentation and should be actively shared with the wider archaeological community. There is, however, an interesting observation to be made here. As discussed, a REST service exists and while this is clearly the most potent way for getting data from the web platform, it was never documented and communicated as a viable option for external consumption. Interestingly, no such identifiable need appears to exist with archaeologists: enquiries related to data consumption are mostly about GIS shapefiles or CSV-files, never about an entire REST service. For instance, even though Flanders Heritage publishes full SKOS-compatible linked open data for its thesauri, it receives regular requests to provide those data in CSV-format instead. While a REST service might offer the most detailed access to the data, it might be technologically too advanced for most users. Thirdly, the published JSON data could be elevated to the level of true linked data by upgrading it to an RDF serialisation format, the most obvious choice being JSON-LD. However, this is not a trivial undertaking, and again there does not seem to be a discernible need. This raises the question whether some of the goals of formal linked open data publishing are currently too advanced and abstract to fulfil an actual need by the users of Flanders Heritage's digital archives. In any case, a solid foundation for a Linked (Open) Data infrastructure is already present.

One should bear in mind that the archaeological digital archiving landscape described in this article corresponds to the situation since the new heritage legislation took effect in 2016. Archaeological research conducted under previous legislation did not have the obligations mentioned above. Yet, even without these formal obligations, a lot of information was shared. Under the previous legislation, i.e., the Archaeology Decree (Dutch Archeologiedecreet, cf Vlaamse Gemeenschap 1993), it was customary for archaeologists to send an analogue or digital report to (the precursor of) Flanders Heritage after an excavation finished. There were no clear rules or guidelines on what had to be included in these reports, just common practice. Often, the archaeologists would not only send their reports, but also their entire digital research archive. Flanders Heritage has published these older reports on a web platform that serves as an open archive for publications and stores all complementary data provided by the 
archaeologists both in its analogue and offline digital archives. These archives can be accessed on request. It is worth noting that these online reports attract considerable interest and that they are downloaded regularly.

Agentschap Onroerend Erfgoed 2019 Code van Goede Praktijk voor de uitvoering van en rapportering over archeologisch vooronderzoek en archeologische opgravingen en het gebruik van metaaldetectoren (versie 4.0). https://www.onroerenderfgoed.be/decode-van-goede-praktijk [Last accessed: 30 November 2020].

Buyle, R., Vanlishout, Z., Coetzee, S., De Paepe, D., Van Compernolle, M., Thijs, G., Van Nuffelen, B., De Vocht, L., Mechant, P., De Vidts, B. and Mannens, E. 2019 'Raising interoperability among base registries: the evolution of the Linked Base Registry for addresses in Flanders', Journal of Web Semantics 55, 86-

101. https://doi.org/10.1016/..websem.2018.10.003

De Langhe, K. 2018 'Vlaams Depotnetwerk. De weg naar een netwerk voor erkende onroerenderfgoeddepots', Onderzoeksrapporten agentschap Onroerend

Erfgoed 103. https://oar.onroerenderfgoed.be/item/2762

Mortier, S., Van Daele, K. and Meganck, L. 2017 'Calling it what it is. Thesauri in the Flanders Heritage Agency: history, importance, use and technological advances', ISPRS Annals of the Photogrammetry, Remote Sensing and Spatial Information Sciences IV2/W2, 151-56. https://doi.org/10.5194/isprs-annals-IV-2-W2-151-2017

Ribbens, R. and De Groote, K. 2020 'Evaluatie archeologie 2019. Evaluatie van het Onroerenderfgoeddecreet - hoofdstuk Archeologie voor het werkjaar 2019', Onderzoeksrapporten agentschap Onroerend Erfgoed 148. https://oar.onroerenderfgoed.be/item/5445

Van Daele, K., Vermeyen, M., Mortier, S. and Meganck, L. 2018 'When data meets the enterprise: how Flanders Heritage Agency turned a merger of organisations into a confluence of information' in M. Matsumoto and E. Uleberg (eds) Oceans of Data. Proceedings of the 44th Conference on Computer Applications and Quantitative Methods in Archaeology, 2016, Oxford: Archaeopress. 273-83.

Vlaamse Gemeenschap 1993 Decreet houdende bescherming van het archeologisch patrimonium. http://www.ejustice.just.fgov.be/eli/decreet/1993/06/30/1993035970/justel [ Last accessed: 30 November 2020].

Vlaamse Overheid 2017 Vlaamse URI-standaard voor data, versie 1.0. https://overheid.vlaanderen.be/sites/default/files/media/documenten/ict-egov/egovernement/open-data/VlaamseURI-StandaardVoorData V1.0.pdf [Last accessed: 30 November 2020].

Vlaamse Overheid 2018 Smart Flanders, Open Data Charter. https://smart.flanders.be/open-data-charter [Last accessed: 30 November 2020]. 
Vlaamse Regering 2011 Een concept van beleid met betrekking tot open

data. https://overheid.vlaanderen.be/sites/bz.vlaanderen.be/files/VR 20112309 DOC 0959-1 BIS Beleid met betrekking tot open data.pdf [Last accessed: 30 November 2020].

Vlaamse Regering 2014 Besluit betreffende de uitvoering van het Onroerenderfgoeddecreet van 12 juli 2013 (citeeropschrift het Onroerenderfgoedbesluit van 16 mei

2014). https://codex.vlaanderen.be/PrintDocument.ashx?id=1024695\&datum=\&geannot eerd=false\&print=false\#H1068365 [Last accessed: 30 November 2020].

Vlaams Parlement 2013 Decreet betreffende het onroerend erfgoed (citeeropschrift het Onroerenderfgoeddecreet van 12 juli

2013). https://codex.vlaanderen.be/PrintDocument.ashx?id=1023317\&datum=\&geannot eerd=false\&print=false [Last accessed: 30 November 2020].

Wilkinson, M., Dumontier, M., Aalbersberg, I. et al. 2016 The FAIR Guiding Principles for scientific data management and stewardship. Scientific Data 3(1),

160018. https://doi.org/10.1038/sdata.2016.18 